\section{International Scientific Journal Theoretical \& Applied Science}

p-ISSN: 2308-4944 (print) e-ISSN: 2409-0085 (online)

Year: $2016 \quad$ Issue: $1 \quad$ Volume: 33

Published: $30.01 .2016 \quad$ http://T-Science.org
Eugene Vasil'evna Vinogradova

Associate Professor, Candidate of Philosophycal Science, Assistant professor Department of History and Philosophy, State Maritime University Admiral Ushakov, Russia, grape3@yandex.ru

SECTION 30. Philosophy.

\title{
PROBLEMS DEVELOPMENT OF HISTORICAL MEMORY
}

Abstract: The article raises the question of historical memory, the need patriotic education, formation of the national way of understanding the world, the existence of it, for the people - it etnogenecal community aware of their genetic connection with other representatives of the people.

Key words: historical memory, national culture, nationalism, the nation, the historical approach, identity, national character, patriotism, cultural archetypes, self.

Language: Russian

Citation: Vinogradova EV (2016) PROBLEMS DEVELOPMENT OF HISTORICAL MEMORY. ISJ Theoretical \& Applied Science, 01 (33): 169-173.

Soi: http://s-o-i.org/1.1/TAS-01-33-30 Doi: crossef http://dx.doi.org/10.15863/TAS.2016.01.33.30

УДК 1:3+930.1

\section{ПРОБЛЕМЫ РАЗВИТИЯ ИСТОРИЧЕСКОЙ ПАМЯТИ}

Аннотация: $B$ статье поднимается вопрос об исторической памяти, о необходимости патриотического воспитания, формирования наџионального способа осознания мира, существования в нем, ибо народ - это этногенетическая общность, осознающая свою генетическую связь с другими представителями данного народа.

Ключевые слова: историческая память, национальная культура, начионализм, начия, исторический подход, самосознание, национальный характер, патриотизм, культурныле архетипь, самоназвание.

В глобализирующемся мире все как-бы подвергаются унификации: избирается ли «президент» или «парламент», устанавливается «валюта» (доллар, евро и др.) и например, таможня, армия, «посольства», т.е. появляется стремление «быть как все». «За это воюют, убивают, «взрывают храмы, жгут архивы чужие и свои, уничтожая свой генофонд, уничтожают и невосстановимые памятники старины-сокровища национальной культуры». [4. - С.384] Свежий пример: события в Украине (февраль-май 2014 г.) Националисты уничтожают памятники Ленину, но самое удивительное, что под топор пошли и, скажем, памятники М.И.Кутузову ибо, очевидно, не знают эти разрушители своей истории, не знают, например, того, что Михаил Илларионович Кутузов воевал за эти земли и здесь он потерял глаз, здоровье. Но нынешняя память у нынешних националистов коротка: они плохо знают историю своей страны и, очевидно, не хотят ее знать, и борются они, по Гачеву, своеобразным образом: уничтожают старое», т.е., по-существу, свою самобытность своеобразным образом: убийством, разрушением, зверством, всевыравнивающей и нивелирующей «смертью» [4]. Но вопрос о национальноуникальном остается острым. И хотя человечество едино в своем развитии - по своим корням. Но в процессе истории оно «разветвляется» на множество разнообразных, локальных и национальных культур. Каждая из них, оказавшись в специфических условиях жизни (географических, исторических, бытовых и технологических) развивает свою историю, вырабатывают свой язык, свое мировидение. Все богатство бытия данной культуры, вся целостность бытия данного народа формирует своей определенный способ осознания мира и существования в этом мире. Результатом этого специфического видения мира, в котором обитает человек и есть, по-Гачеву, культурная картина мира, как система образов. представлений, знаний об устройстве мира и места в нем человека. Важнейшими компонентами картины

ISPC Perspectives in science for 2016, 
мира является: культурные нормы, ценности, системы образов и представлений, способы мировосприятия, культурные архетипы [4].

Поэтому необходимо неторопливое, вдумчивое вникание в константы каждого национального мира, в присущие ему особенности [5, с.13]. На формирование этих особенностей влияют и природа данной страны, язык, обычаи, психика, «ментальность» народа. Они - основа самости каждой страны, народа, его самобытности. Помимо названных выше условий, которые скрепляют народ в единое целое, важно, применяя исторический метод, исторический подход, понять то, что делает народ единой целостностью. То общее, что объединяет их в целостность - это биография народа, запечатленная в памяти. Таким образом, народ цементируется в единое целое, его историей. Которая сохраняется в социальной памяти - культуре. Элементом этой памяти является самоназвание. Оно выделяет данный народ среди других людей и позволяет им фиксировать различие между «мы» и «они». С самоназванием связано и самосознание сознание своей принадлежности к этому «мы», к данному народу. При этом это осознание носит не просто осознание общности. Народ этногенетическая общность, осознающая свою генетическую связь с другими представителями данного народа. Этническое самосознание индивида строится на его представлениях о своем происхождении, ибо он полагает себя потомком ряда поколений предков, принадлежащих к данному этносу. Из поколения в поколение передается память о предках. Это и образует историческую наследственность, которая и определяет целостность этноса. И еще. Этническая память основана не только на «крови», а на самосознании людей, а поэтому что это понятие не только онтологическое, но, скорее, социальное, вернее сказать, биосоциальное. Но и это еще не все. Л.Н.Гумилев ввел в учение об этносе системный подход. Между людьми внутри этноса существует определенная целостность, системная связь между людьми. И благодаря этому эти общности, эти коллективы не случайно обладают общностью поведенческих черт, передаваемых из поколения в поколение с помощью механизма условно-рефлекторной сигнальной наследственности. Эти черты не случайны, они вырабатываются в процессе адаптации людей в этнической и ландшафтной среде и образует свой стереотип поведения этноса. [6]

Вот этот стереотип поведения, по Гумилеву, служит фундаментом этнической традиции, включающей в себя культурные и мировоззренческие устои, формы общежития и хозяйства, имеющие в каждом этносе неповторимые особенности.

Но Н.А.Бердяев в статье «О власти пространства над русской душой» указал и на то, что необъятные пространства России тяжким гнетом легли на душу русского народа... Русская душа ушиблена ширью, она не видит границ, и эта безграничность не освобождает, а порабощает ее... Русский человек, человек земли чувствует себя беспомощным овладеть этими пространствами и организовать их. Именно поэтому у русских людей преобладает нагляднообразное и наглядно-действенное мышление, а у западных - вербально-логическое.

Как у всякого народа, у славянства была своя языческая культура. И именно славянское язычество и было тем духовным началом, в котором формировались своеобразные черты славянского этноса. Одухотворение природы, ощущение целесообразности в жизни природы, «населения ее всевозможными духоматериальными существами», и, особое, характерное для русского самосознания, понимание мира как единого целого «связаны с архитипическими идеями славянского язычества». [9] Так же, исходящей из мировоззрения древнего славянства можно считать идею единства человеческого рода, которую позже восприняла русская философия. Это идея русской философии о всечеловеческом единстве до идеала соборности по мнению А.Г.Заседателевой, - «близко к этому находится и архитипическое чувство, изначально присущее всем народам - патриотизм». Но она подчеркивает, что патриотизм русского народа особый т.к. только народу России присуща приоритетная во многом над личностным благополучием любовь к Родине, патриотизм, соединенный с идеалами заботы обо всем человечестве, что непосредственно выражено отечественной историей и философией». [9 C.53] И историческое предание - как приобщение к историзму у русских.

Таким образом, специфику русского национального менталитета, существенные отличия русской «народной души», русского характера во многом определяются славянскими архитипическими идеями древних славян. И, наконец, - подчеркивает Заседателева, культурное своеобразие русской нации... обусловлено влиянием славянских архетипов». [9]

И, понятно, чтобы лучше понять самих себя, «свою душу» неплохо бы изучать «преданья старины глубокой». Например, долго существовала устная традиция передачи важной информации от одного поколения к другому. И М.Ю.Лермонтов в своем знаменитом стихотворении «Бородино» передает читателям 
впечатления об этом знаменитом сражении как бы от первого лица - участника этих событий, усиливая ценность и значимость события глазами очевидца: «Скажи-ка, дядя, ведь недаром Москва, спаленная пожаром, французу отдана? Ведь были схватки боевые, да говорят, еще какие? Недаром помнит вся Россия про день Бородина!».

Да, вся Россия до последнего XXI века хорошо знала и помнила о войне 1812 г.. Патриотический подъем в России был настолько велик, что события тех лет как бы «впаялись» в память всех поколений жителей России. Недавно отмечали 200-летие этой Победы в нашей стране. Надо сказать, что особого подъема в праздновании этой даты не происходило. Да, 200 лет - срок немалый, но для России эта Победа имела огромное историческое значение. И это должны знать все жители страны и сейчас, тем более, что другая для нас весьма памятная дата 9 мая - День Победы над фашистской Германией в Великой Отечественной войне 1941-1945 гг. Тем более, что эта победа досталась нам нелегко - большими людскими потерями это около 27 млн человек! Как же память о погибших у нас должна проявляться?! Разве «пепел этих 27 млн человек, как говорил Шарль де Костер, не должен «стучать в наших сердцах»? А что на деле? Не все здесь обстоит благополучно. Так, на занятиях по истории в университете, на вопрос преподавателя: кто такой Гитлер, один курсант ответил, что это один из военачальников Красной Армии! Разве это допустимо, разве это не серьезные издержки школьного образования, разваленного за постперестроечные годы? Примеров плохого знания истории своей страны можно привести множество.

Так что же такое историческая память и как следует воспитывать подрастающие поколения, на каких примерах из современной жизни нашего общества?

В работе «Смысл истории» Н.Бердяев говорит об этом так: «...если человек смог связать свою духовную судьбу с духовной судьбой истории, то человек в своей настоящей жизни, во многих духовных актах находит истинную реальность великого исторического мира через историческую память, через внутреннее предание, через внутреннее приобщение судеб своего индивидуального духа к судьбам истории. Таким образом он [как бы не выпадает из истории] приобщается к бесконечно более богатой действительности, он тем самым побеждает тленность и малость свою, преодолевает свой бедный и суженный кругозор». [2 - С.17] Более того, Бердяев подчеркивает, что историческая память, которая заставляет нас внутренне приобщаться к «историзму», неразрывно связана с историческим преданием».[2. - С.17] Что для нас война 1812 года как не предание? И.Н.Бердяев говорит, что историческое предание и есть эта внутренняя историческая память, перенесенная в историческую судьбу.

Философия истории, - по Бердяеву, - и есть некоторое одухотворение и преображение исторического процесса. Она есть памятник победы духа нетления над духом тления. Пример тому - стихотворение М.Ю.Лермонтова «Бородино», то место, в котором полковник призывает воинов к подвигу: «Ребята, не Москва ль за нами? Умремте ж под Москвой, как наши братья умирали!» И умереть мы обещали и клятву верности сдержали мы в Бородинский бой!» Эти слова потом были произнесены во время Второй Мировой войны при битве под Москвой. Поэтому в исторической памяти, в обращении к прошлому, есть, по Бердяеву, всегда какое-то особое чувство приобщения к другому миру, а не только к тому реальному миру, который нас со всех сторон давит, как кошмар и которую мы должны победить, чтобы подняться на какую то новую высоту, к той исторической действительности, которая есть не что иное как «подлинное откровение иных миров».[2. -с.17] И судьба отдельного человека, таким образом, неразрывно связана с человечеством, в их приобщении к духовной сущности мира, у такого человека нет эгоизма, он - часть целого и поэтому понимает, что только совместное делание в конце концов может привести общество на более высокую ступень развития. И особенность человека как личности как социального существа, по Бердяеву, заключается в том, что только она олицетворяет в себе эту социальность, ибо ни общество, ни государство, ни нация не являются личностями, поэтому только человек как личность имеет большую ценность, чем они. [2] Но великое историческое событие - оно есть совместное делание истории. Так, совместное переживание войны, горя, совместная борьба за свободу страны, борьба с трудностями, лишениями, голодом сделала советский народ великим народом, сломавшем грозного врага. И «головокружения от успехов» в послевоенном восстановлении страны у того поколения не было, и ожидание будущего благополучия было естественным результатом их совместного труда. Но гордость за свои большие дела у старшего поколения была, ибо гордиться было чем! СССР вначале 1970-х годов был великой державой, которая к началу 80-х годов таки построила постиндустриальное общество и в целом догнала США по уровню экономического, социального, научного и культурного развития.

Что же стало потом с нами и во что мы теперь превратились? Есть ли в нашей теперешней России тот стержень, та основа, то 
звено, за которое можно потянуть, чтобы вытянуть страну, которую сейчас любить в общем -то не за что, но которой можно в дальнейшем гордиться, если Россия встанет на путь конструктивного нравственного существования.

Ведь еще Сухомлинский сказал, что без цели, без идеи коллектив (общество) умирает. Какая же цель стоит перед нашим обществом, куда зовет нас наш авангард - наша власть? Какую идеологию выработали наши идеологи во власти?

Наше общество живет в условиях существования не одной государственной идеологии, как это есть в каждом нормальном государстве, а как минимум в двух. В Конституции РФ ст.13, пункт 2 даже записано, что «никакая идеология не может устанавливаться, в качестве государственной или обязательной». Какую же неправду здесь протащили ее авторы? Ведь ни одно общество не может существовать без государственной идеологии. И она есть у нас. Долго политологи, идеологи мучительно искали под каким же девизом наше общество развивается? Поиски закончились тем, что официальной идеологией стала называться, считаться христианская идеология. Государство, несмотря на бедственное положение народа, усиленно субсидировало и (продолжает это делать сейчас) на воссоздание разрушенных и строительство новых церквей. Но, одна «нестыковка» здесь возникла. Ведь наше общество - многоконфесиональная страна и объявлять христианство государственной религией оказалось неудобным и даже опасным. Возникла идея державности. Особенно она «обосновалась» на Кубани, а вместе с ней и идея патриотизма. Но мало-помалу эта идея потерпела неудачу на фоне провала приоритетных национальных проектов: 1) современное образование, 2) жилье доступное и комфортное; 3) «качественное здравоохранение». Национальные проекты определялись стратегическими интересами государства во внутренней и внешней сферах жизнедеятельности общества. Программы утверждали основные направления развития науки и техники, которые нацелены на поддержание сферы фундаментальных и стратегических исследований, обеспечение взаимосвязи науки и производства, что позволило бы укрепить обороноспособность страны, обеспечить функционирование науки и экономики, поддержание национальных производителей на мировом и внутреннем рынках, ресурсное обеспечение и ресурсосбережение, здравоохранение, охрану окружающей среды и как следствие этих планов - повышение благосостояния народа страны.
Это громадье планов, однако, не осуществилось, ибо кроме сырьевой сферы ни одна сфера жизнеобеспечения общества не действует эффективно. Образование разрушено («памятник» пора ставить г.Фурсенко!), здравоохранение превратилось в нездравоохранение, ибо «врачебная помощь» такова, что от «ошибок» врачей умирает ежегодно людей больше, чем от гибели людей на транспорте. $30 \%$ всех смертей в стране, приходится на эти «ошибки». А жилищное строительство хотя и идет, но оно не доступно для большинства населения. Перед выборами президента власть хвастала, что она чуть ли не спасла страну от гибели. А разве страна еще жива? Если жива, то по показателю качества жизни наша страна занимает чуть-ли не предпоследнее место в мире. И это в самой богатой стране мира? И в стратегических планах развития нашего общества попрежнему отсутствует главная задача - задача создания условий для комфортного проживания каждого человека в РФ, программа обеспечения прав и свобод личности. Напротив, демократические преобразования заглохли и теперь уступают место антидемократическим мерам и законам, в экстренном порядке принимаемыми нашими думцами. Как заметил А.Хреков в статье «Новые горизонты А.Хрекова» в газете «Аргументы недели», что современные правители отделили себя от народа. Они давно не видят тут своего будущего... ибо их «дети там» (за границей), деньги тоже «там». А «тут» только действие под названием «баблодоение».[10. - с.3] И главная беда наша, по мнению Хрекова - жулики и воры в правительстве. Это враги и терпеть их нельзя».[10. -с.3] Беспредел в экономической сфере ведет к обнищанию народа и, как следствие, - к обесценению культуры как феномена.

Поэтому нужен глубокий поворот от всеобщего бескультурья (как во власти, так и у народа).

Но постепенно, без особого муссирования идеи развития набирали в нашем государстве свою силу и мощь. И координатором, главной фигурой этого перелома ситуации от стагнации к скачку в политике, экономике, культуре, стал В.В.Путин. Этот курс на подъем всех сфер жизни c особой силой продемонстрировала зимняя Олимпиада в Сочи. Наконец-то появилась личность, которая взяла на себя ответственность за совершаемое в обществе. Теперь появился человек - патриот, о котором можно было только мечтать. И таким человеком стал нынешний Президент страны Владимир Владимирович Путин. К своему триумфу, как общественного деятеля, как выразителя интересов и чаяний многострадального российского человека Путин 
шел долгим путем скрупулезно собирая свою команду, которая была бы тем ядром, вокруг которого объединился, наконец, наш народ. Нелегко было преодолеть негативные тенденции. Во властвующей элите сильны были силы противостояния. Но, как сам выразился В.В.Путин, я много переосмыслил и уже не нуждался в разнообразных «советчиках». Прежде чем стать безоговорочным лидером, он разработал безошибочную стратегию своего возвышения в международной политике, военной реформе. Олимпиада стала важным объединяющим событием, перевернувшим и наше российское общество, но и весь мир: самым важным последствием Олимпиады и Паралимпиады то, что они выступили решающим объединяющим началом. Расколотое на куски, на отдельные слои общества, Россия вдруг стала державой. Она как бы «очнулась», расправила крылья, почувствовала себя единым общественным организмом.

Но последующие трагические события на Украине, пробуждение и в этой стране национального самосознания, присоединение Крыма к России, где В.В.Путин раскрыл еще ярче свои качества талантливого, прозорливого, решительного, но в то же время и осторожного и мудрого лидера, да так, что о нем заговорили на высокомерном Западе, как о личности огромного масштаба. Это многого стоит, чтобы недоброжелатели тебя зауважали!

Россия, наконец, показала свою силу и свой характер. И как здесь не вспомнить И.А.Ильина, который говорил о том, что враги наши хотят видеть нашу страну слабой, увязшей в страшных дебрях раздора и распада. И он же говорил о том, что они (враги и недоброжелатели) ненавидят сильную Россию и готовы пойти на всякие подлости, чтобы ослабить и уничтожить Россию. И теперь мы воочию убедились, что они желают видеть Россию, раздробленную «в кусочки» и рвут и мечут, чтобы теми или иными мерами ослабить, унизить и даже уничтожить Россию! Вот истинное лицо США и ее саттелитов! Нам теперь важно в массовом масштабе обнаружить, проявить свой национальный русский характер.

\section{References:}

1. Berdyaev NA (1990) The origins and meaning of Russian communism. "Nauka", 1990.

2. Berdyaev NA (1990) The meaning of history. Moscow, 1990.

3. Berdyaev NA (2000) Russian idea. - Moscow.: AST-folio. - 2000.

4. Gachev G (2003) National images of the world. Russia's neighbors: Poland, Lithuania, Estonia. - Moscow: Progress -traditsiya. 2003 - p.384.

5. T. Gachev National images of the world: lectures. - Moscow: Academy, 1998. p.432.

6. LN Gumilyov (2004) From Russia to Russia: Essays ethnic theory. - Moscow: Ekopros, 2004. - p.336.
7. LN Gumilyov (1993) Ethnosphere: history and the history of nature. - Moscow: Ekopros. 1993 p. 544.

8. Gurevich L (1994) Philosophy of Culture. Moscow: Aspect Press, 1994. p.380.

9. Zasedateleva AG (2007) Paganism as a cultural phenomenon. - Krasnodar, Kuban People's Academy. 2007.

10. A. Khrekov (2012) New Horizons A.Hrekova // "Arguments of the Week". Number 25, 2012, p.5. 